Article

\title{
Soil Type and Zinc Doses in Agronomic Biofortification of Lettuce Genotypes
}

\author{
Hilário Júnior de Almeida ${ }^{1}\left(\mathbb{D}\right.$, Victor Manuel Vergara Carmona ${ }^{1,2, *(1)}$, \\ Maykom Ferreira Inocêncio ${ }^{3}$, Antônio Eduardo Furtini Neto ${ }^{3}$, Arthur Bernardes Cecílio Filho ${ }^{1}$ \\ and Munir Mauad ${ }^{4}$ \\ 1 Faculdade de Ciências Agrárias e Veterinárias, Universidade Estadual Paulista (UNESP), \\ Jaboticabal 14884-900, São Paulo, Brasil; hilarioagro@yahoo.com.br (H.J.d.A.); \\ arthur.cecilio@unesp.br (A.B.C.F.) \\ 2 Facultad de Recursos Naturales Renovables, Universidad Arturo Prat (UNAP), \\ Iquique 1100000, Región de Tarapacá, Chile \\ 3 Departamento de Ciências do Solo, Universidade Federal de Lavras, Lavras 37200-000, Minas Gerais, Brasil; \\ maykominocencio@gmail.com (M.F.I.); furtinineto@gmail.com (A.E.F.N.) \\ 4 Faculdade de Ciências Agrárias, Universidade Federal da Grande Dourados (UFGD), \\ Dourados 79804-970, Mato Grosso do Sul, Brasil; munirmauad@ufgd.edu.br \\ * Correspondence: vivergara@unap.cl; Tel.: +56-9-95875252
}

Received: 29 November 2019; Accepted: 8 January 2020; Published: 15 January 2020

check for updates

\begin{abstract}
The incidence of many malnutrition-related diseases among the populations of developing countries is closely related to low dietary zinc $(\mathrm{Zn})$ intakes. This study evaluated the potential of agronomic biofortification of lettuce genotypes with $\mathrm{Zn}$ in different soils. We evaluated the ability to biofortify three lettuce genotypes ('Grand Rapids', 'Regina de Verão', and 'Delícia') in two soils (Red-Yellow Latosol and Dystroferric Red Latosol) using five doses of Zn (0, 5, 10, 20, and $30 \mathrm{mg} \mathrm{kg}^{-1}$ ). At 55 days after sowing, the plants were harvested. There was an interaction among the soils, genotypes, and $\mathrm{Zn}$ doses. Regardless of the soil and genotype, the increase in $\mathrm{Zn}$ supply promoted a linear increase in shoot $\mathrm{Zn}$ concentration. However, shoot and root dry matter yields were differentially affected by Zn supply according to the genotype and soil type. Overall, the Red-Yellow Latosol provided a higher shoot $\mathrm{Zn}$ concentration but also caused greater growth damage, especially in 'Regina de Verão' and 'Delícia'. 'Grand Rapids' was biofortified the most in Red-Yellow Latosol.
\end{abstract}

Keywords: Lactuca sativa; nutritional value; cultivars; micronutrient; food safety

\section{Introduction}

The population growth rate on the planet is $1.08 \%$ per year. The current population count is around 7.6 billion [1]. It is estimated to exceed nine billion by 2050 [2]. Considering that the primary sources of nutrients come directly or indirectly from foods produced by agriculture, this population increase strongly pressures the environment to meet such a demand [3,4]. Increasing crop yields has been important for reducing global undernourishment from about 19\% to 13\% between 1990 and 2010 [5]. However, micronutrient deficiency currently affects almost half of the world's population, and $\mathrm{Zn}$ deficiency is one of the major public health concerns in developing countries [6].

In humans, Zn deficiency is associated with poor dietary diversification [7] and is exacerbated by its poor availability in soils [8]. Tropical soils present naturally low fertility and low $\mathrm{Zn}$ concentration (0.6 to $2.0 \mathrm{mg} \mathrm{kg}^{-1}$ ), affecting approximately $90 \%$ to $95 \%$ of the native Brazilian Cerrado soils [9]. Moreover, the availability of this micronutrient is dependent on several soil properties, such as $\mathrm{pH}$ or capacity for phosphorus adsorption [10]. Thus, fertilization with $\mathrm{Zn}$ is a good strategy to enrich 
agricultural products and increase the daily Zn intake of the population [11-13], especially for those who consume it in small amounts daily. According to the National Research Council, the recommended dietary allowance (RDA) of $\mathrm{Zn}$ that an adult needs is about $11 \mathrm{mg}$; however, one-fifth of the world's population consumes deficient quantities of this micronutrient [6].

In this sense, agronomic biofortification seeks to increase the nutrient concentration and bioavailability in the edible parts of plants. It is considered the most economical solution for micronutrient deficiency in humans and animals [14]. Several studies have shown that $\mathrm{Zn}$ fertilization is efficient at increasing the $\mathrm{Zn}$ concentration in foods $[13,15,16]$. Yet, leafy vegetables are more suitable for achieving higher $\mathrm{Zn}$ concentrations than fruits, tubers, or seeds, since $\mathrm{Zn}$ is mainly transported through the xylem of plants [8,17]. White et al. [16] found a linear increase in shoot $\mathrm{Zn}$ concentrations in different cabbage and broccoli genotypes grown under $\mathrm{Zn}$ applications with the $\mathrm{Zn}$ nitrate as the substrate. Those authors found a wide range of critical shoot $\mathrm{Zn}$ concentrations for cabbage (74-1201 mg kg${ }^{-1}$ ) and broccoli (117-1666 $\mathrm{mg} \mathrm{kg}^{-1}$ ), which exceeded the estimated potential for $\mathrm{Zn}$ biofortification of leafy vegetables (up to $700 \mathrm{mg} \mathrm{kg}^{-1}$ ) [17]. For lettuce, the range of optimal leaf $\mathrm{Zn}$ concentrations is 20 to $60 \mathrm{mg} \mathrm{kg}^{-1}$ [18]. However, Padash et al. [19] found increases up to $185 \mathrm{mg} \mathrm{kg}^{-1}$ without toxicity effects on lettuce growing with $10 \mathrm{mg} \mathrm{L}^{-1}$ of $\mathrm{Zn}$. This could be a significant contribution as a biofortified crop, since lettuce is the main leafy horticultural produce worldwide, with a production increase of about $62 \%$ in the least two decades [20].

Although studies have been carried out to prove the agronomic efficiency of Zn biofortification in agricultural products, it is interesting to address genotype-soil interactions and their effects on agronomic biofortification efficiency $[8,17]$.

Thus, a better understanding of how $\mathrm{Zn}$ biofortification of lettuce is influenced by production factors may provide greater efficiency for this technology. This study evaluated the response of lettuce genotypes to $\mathrm{Zn}$ application for biofortification in two soils.

\section{Materials and Methods}

\subsection{Location and Experimental Design}

The experiment was carried out in greenhouse conditions at the Federal University of Lavras, Brazil ( $21^{\circ} 13^{\prime} 35^{\prime \prime} \mathrm{S}, 44^{\circ} 58^{\prime} 43^{\prime \prime} \mathrm{W}$, altitude of $\left.918 \mathrm{~m}\right)$. According to Koppen's classification (1936), the climate is humid subtropical (Cwa), mesothermal, with dry winters and the temperature of the coldest month is between -3 and $18{ }^{\circ} \mathrm{C}$, with a rainy subtropical summer. The temperature of the hottest month is higher than $22^{\circ} \mathrm{C}$.

The experiment was completely randomized and distributed in a $5 \times 3 \times 2$ factorial design, as follows: Five doses of $\mathrm{Zn}\left(0,5,10,20\right.$, and $\left.30 \mathrm{mg} \mathrm{kg}^{-1}\right)$ as $\mathrm{Zn}$ sulphate $\left(\mathrm{ZnSO}_{4}\right)$, three lettuce genotypes ('Grand Rapids', 'Regina de Verão', and 'Delícia'), and two soil types (Red-Yellow Latosol, RYL; and Dystroferric Red Latosol, dRL) in three replications.

\subsection{Installation and Conduction of the Experiment}

Samples from two soils were collected at a depth of $0-20 \mathrm{~cm}$. The dRL and RYL samples were collected from a native forest and grazing soil, respectively, of the Lavras municipality. They were air-dried, sieved to $<2 \mathrm{~mm}$, and subjected to physicochemical soil analysis according to Corguinha et al. [10] and mineralogical analysis according to Souza et al. [21] (Table 1). 
Table 1. Physicochemical and mineralogical features of Red-Yellow Latosol (RYL) and Dystroferric Red Latosol (dRL) at the $0-20 \mathrm{~cm}$ layer.

\begin{tabular}{|c|c|c|c|c|c|}
\hline \multirow{2}{*}{ Soil Attribute } & \multicolumn{2}{|c|}{ Soil } & \multirow{2}{*}{ Soil Attribute } & \multicolumn{2}{|c|}{ Soil } \\
\hline & RYL & $\mathrm{dRL}$ & & RYL & $\mathrm{dRL}$ \\
\hline $\mathrm{pH}\left(\mathrm{H}_{2} \mathrm{O}\right)$ & 5.0 & 4.9 & CEC-T $\left(\mathrm{cmol}_{\mathrm{C}} \mathrm{kg}^{-1}\right)$ & 4.3 & 9.1 \\
\hline $\mathrm{Al}^{3+}\left(\mathrm{cmol}_{\mathrm{C}} \mathrm{kg}^{-1}\right)$ & 0.7 & 1.3 & $\mathrm{~V}(\%)$ & 16.3 & 3.3 \\
\hline $\mathrm{Ca}^{2+}\left(\mathrm{cmol}_{\mathrm{c}} \mathrm{kg}^{-1}\right)$ & 0.4 & 0.1 & Sand $\left(\mathrm{g} \mathrm{kg}^{-1}\right)$ & 730.0 & 240.0 \\
\hline $\mathrm{Mg}^{2+}\left(\mathrm{cmol}_{\mathrm{C}} \mathrm{kg}^{-1}\right)$ & 0.2 & 0.1 & Silt $\left(\mathrm{g} \mathrm{kg}^{-1}\right)$ & 50.0 & 110.0 \\
\hline $\mathrm{K}^{+}\left(\mathrm{mg} \mathrm{kg}^{-1}\right)$ & 41.0 & 37.0 & Clay $\left(\mathrm{g} \mathrm{kg}^{-1}\right)$ & 220.0 & 650.0 \\
\hline $\mathrm{H}^{+}+\mathrm{Al}^{3+}\left(\mathrm{cmol}_{\mathrm{c}} \mathrm{kg}^{-1}\right)$ & 3.6 & 8.8 & Ds $\left(\mathrm{kg} \mathrm{dm}^{-3}\right)$ & 1.2 & 1.0 \\
\hline $\mathrm{P}\left(\mathrm{mg} \mathrm{kg}^{-1}\right)$ & 0.8 & 0.8 & $\mathrm{SiO}_{2}\left(\mathrm{~g} \mathrm{~kg}^{-1}\right)$ & 95.1 & 130 \\
\hline$P$ rem $\left(\mathrm{mg} \mathrm{kg}^{-1}\right)$ & 26.5 & 8.5 & $\mathrm{Al}_{2} \mathrm{O}_{3}\left(\mathrm{~g} \mathrm{~kg}^{-1}\right)$ & 97.4 & 319 \\
\hline $\mathrm{S}\left(\mathrm{mg} \mathrm{kg}^{-1}\right)$ & 6.2 & 7.1 & $\mathrm{Fe}_{2} \mathrm{O}_{3}\left(\mathrm{~g} \mathrm{~kg}^{-1}\right)$ & 36.2 & 172 \\
\hline $\mathrm{B}\left(\mathrm{mg} \mathrm{kg}^{-1}\right)$ & 0.7 & 0.4 & $\mathrm{TiO}_{2}\left(\mathrm{~g} \mathrm{~kg}^{-1}\right)$ & 6.2 & 22.0 \\
\hline $\mathrm{Cu}^{2+}\left(\mathrm{mg} \mathrm{kg}^{-1}\right)$ & 0.9 & 1.7 & $\mathrm{P}_{2} \mathrm{O}_{5}\left(\mathrm{~g} \mathrm{~kg}^{-1}\right)$ & 0.0 & 0.9 \\
\hline $\mathrm{Fe}^{2+}\left(\mathrm{mg} \mathrm{kg}^{-1}\right)$ & 64.7 & 93.4 & $\mathrm{Fe}_{\mathrm{d}}\left(\mathrm{g} \mathrm{kg}^{-1}\right)$ & 10.8 & 102 \\
\hline $\mathrm{Mn}^{2+}\left(\mathrm{mg} \mathrm{kg}^{-1}\right)$ & 5.9 & 3.3 & $\mathrm{Fe}_{\mathrm{o}}\left(\mathrm{g} \mathrm{kg}^{-1}\right)$ & 0.1 & 9.2 \\
\hline $\mathrm{Zn}^{2+}\left(\mathrm{mg} \mathrm{kg}^{-1}\right)$ & 0.6 & 0.8 & $\mathrm{Ct}\left(\mathrm{g} \mathrm{kg}^{-1}\right)$ & 752 & 293 \\
\hline $\mathrm{OM}\left(\mathrm{g} \mathrm{kg}^{-1}\right)$ & 24.0 & 48.0 & Gibbsite $\left(\mathrm{g} \mathrm{kg}^{-1}\right)$ & 63.0 & 359 \\
\hline $\mathrm{BS}\left(\mathrm{cmol}_{\mathrm{c}} \mathrm{kg}^{-1}\right)$ & 0.7 & 0.3 & $\mathrm{Ki}$ & 1.0 & 0.4 \\
\hline CEC-t $\left(\mathrm{cmol}_{\mathrm{C}} \mathrm{kg}^{-1}\right)$ & 1.4 & 1.6 & $\mathrm{Kr}$ & 0.7 & 0.3 \\
\hline
\end{tabular}

$\mathrm{P}$ rem $=$ remaining phosphorus; $\mathrm{CEC}-\mathrm{T}=$ cation exchange capacity at $\mathrm{pH} 7 ; \mathrm{OM}=$ organic matter; $\mathrm{CEC}-\mathrm{t}=$ effective cation exchange capacity; $\mathrm{V}=$ base saturation; $\mathrm{Ds}=$ apparent density; $\mathrm{Ki}=\left(\% \mathrm{SiO}_{2} \times 1.70\right) / \% \mathrm{Al}_{2} \mathrm{O}_{3} ; \mathrm{Kr}=\left(\% \mathrm{SiO}_{2} \times\right.$ $1.70) /\left[\% \mathrm{Al}_{2} \mathrm{O}_{3}+\left(\% \mathrm{Fe}_{2} \mathrm{O}_{3} \times 0.64\right)\right]$. These two indices indicate the degree of change or weathering of tropical soils.

Liming was performed with lime (CaO: $38.8 \%$, MgO: $13.4 \%$, PRNT: 94.4 , Ca: $27.72 \%$, and $\mathrm{Mg} 8.0 \%$ ). The soil remained incubated for 30 days, with $70 \%$ of the total pore volume occupied by deionized water. After the incubation period, soil $\mathrm{pH}$ was 6.0. Then, soil samples received the following basic fertilization: $100 \mathrm{mg} \mathrm{kg}^{-1}$ of $\mathrm{N}, 200 \mathrm{mg} \mathrm{kg}^{-1}$ of $\mathrm{P}\left(\mathrm{MAP}-60 \%\right.$ of $\mathrm{P}_{2} \mathrm{O}_{5}$ and $11 \%$ of N), $100 \mathrm{mg} \mathrm{kg}^{-1}$ of K $(\mathrm{KCl}), 37.5 \mathrm{mg} \mathrm{kg}^{-1}$ of $\mathrm{Mg}, 50 \mathrm{mg} \mathrm{kg}{ }^{-1}$ of $\mathrm{S}\left(\mathrm{MgSO}_{4} 7 \mathrm{H}_{2} \mathrm{O}\right), 0.5 \mathrm{mg} \mathrm{kg}^{-1}$ of $\mathrm{B}\left(\mathrm{H}_{3} \mathrm{BO}_{3}\right), 1.5 \mathrm{mg} \mathrm{kg}^{-1}$ of $\mathrm{Cu}\left(\mathrm{CuSO}_{4} 5 \mathrm{H}_{2} \mathrm{O}\right), 5 \mathrm{mg} \mathrm{kg}^{-1}$ of $\mathrm{Mn}\left(\mathrm{MnSO}_{4} \mathrm{H}_{2} \mathrm{O}\right)$, and $0.1 \mathrm{mg} \mathrm{kg}^{-1}$ of $\mathrm{Mo}\left(\mathrm{Na}_{2} \mathrm{MoO}_{4} 2 \mathrm{H}_{2} \mathrm{O}\right)$. Along with the basic fertilization, the treatments ( $\mathrm{Zn}$ doses) were applied.

Samples of each soil were again incubated for 10 days with $70 \%$ of the total pore volume occupied by deionized water. After this second incubation, the soil samples were individually harrowed. Then, the lettuce was sown, and after seven days, the most vigorous plant was left in each pot containing $5 \mathrm{dm}^{-3}$ of soil. The water was replaced daily. At 25 and 40 days after sowing, $100 \mathrm{mg} \mathrm{kg}^{-1}$ of N $\left(\mathrm{NH}_{4} \mathrm{NO}_{3}\right)$ and $100 \mathrm{mg} \mathrm{kg}^{-1}$ of $\mathrm{K}(\mathrm{KCl})$ were applied as a cover fertilization. Harvesting was performed 55 days after sowing by cutting lettuce plants close to the soil.

\subsection{Growth and Biofortification with $\mathrm{Zn}$}

After harvesting the plants, the shoots and roots were washed with running deionized water, and the samples were placed to dry in a forced air oven at 65 to $70{ }^{\circ} \mathrm{C}$. The shoots (SDM) and roots (RDM) dry matter were determined. Only the shoots were ground and subjected to $\mathrm{Zn}$ analysis. Subsequently, the dried tissues (approximately $200 \mathrm{mg}$ ) were weighed and acid-digested in $2.0 \mathrm{~mL}$ of $\mathrm{HNO}_{3}$ with $2.0 \mathrm{~mL}$ of $\mathrm{HClO}_{4}$ at $120^{\circ} \mathrm{C}$ for $60 \mathrm{~min}$, and then at $220^{\circ} \mathrm{C}$ until $\mathrm{HClO}_{4}$ fumes were observed. The $\mathrm{Zn}$ concentration in SDM was determined by an atomic absorption spectrophotometer (PerkinElmer Inc., AAnalyst $800^{\circledR}$, San Jose, CA, USA). A standard reference material from the National Institute of Standards and Technology (NIST 1573a containing $30.94 \mathrm{mg} \mathrm{kg}^{-1}$ of Zn), as well as a blank sample were used in each batch of digestion for quality assurance and quality control in $\mathrm{Zn}$ determinations, which were considered satisfactory ( $>90 \%$ recovery). 


\subsection{Statistical Analysis}

Data were subjected to analysis of variance and, when significant at $5 \%$ by the $\mathrm{F}$ test, a polynomial regression analysis was performed for $\mathrm{Zn}$ doses. The significant equations with the highest coefficient of determination were chosen $\left(R^{2}\right)$. Linear correlation analyses were also performed between the $\mathrm{Zn}$ contents of the lettuce genotypes and the $\mathrm{Zn}$ doses applied to the soil. Analyses were run on the AgroEstat software [22].

\section{Results}

\subsection{Growth of Lettuce Genotypes}

The growth of the three lettuce genotypes varied, and it was affected by soil types and $\mathrm{Zn}$ doses. The shoots of lettuce genotypes were always larger when they were grown in RYL. However, Zn application caused a significant reduction in the shoot dry matter (SDM) of 'Regina de Verão' and 'Delícia' genotypes grown in RYL, which was not observed when grown in dRL (Figure 1).
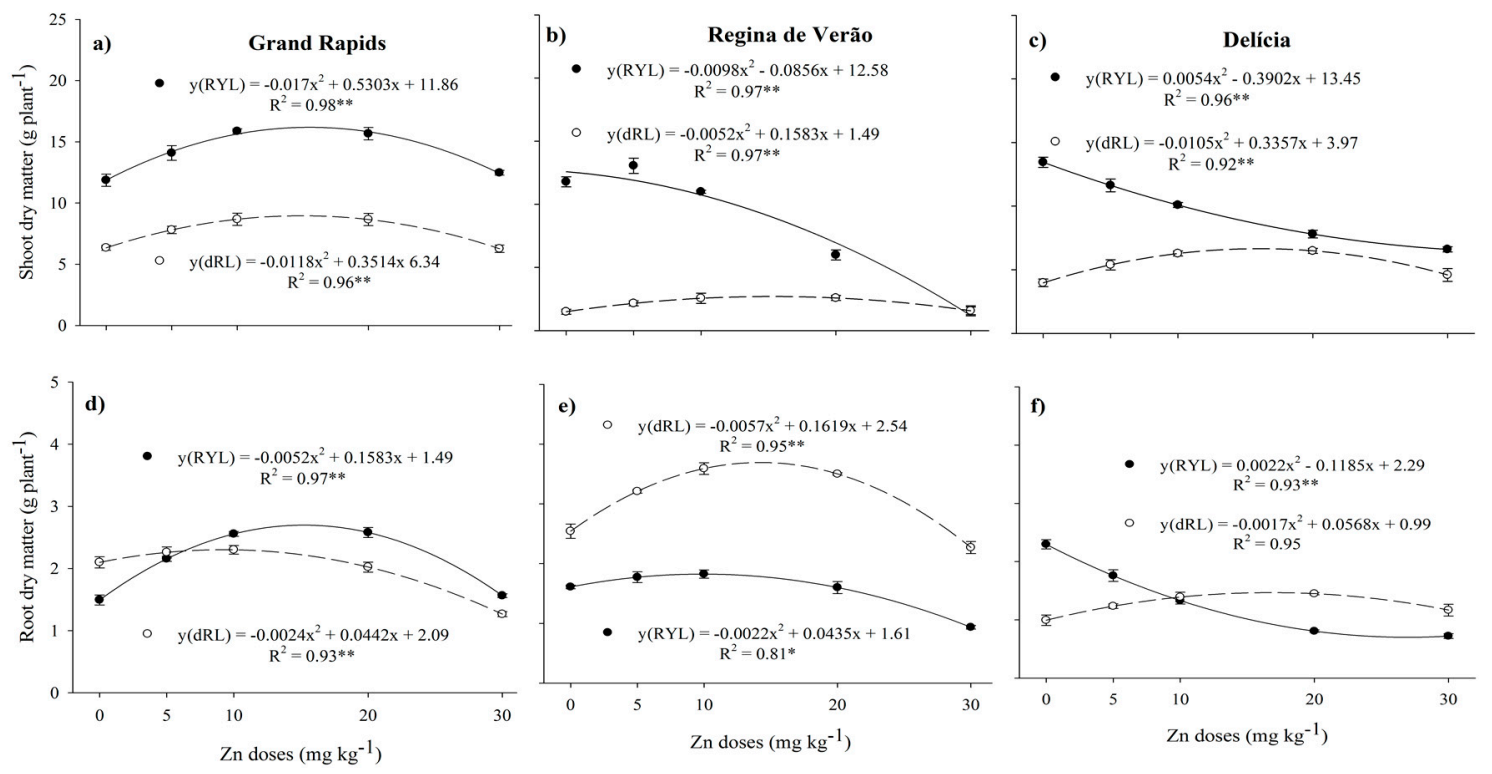

Figure 1. Shoots and roots dry matter of three lettuce genotypes grown in Red-Yellow Latosol (RYL) and Dystroferric Red Latosol (dRL) with different Zn doses. (a,d) presents the dry matter production in 'Grand Rapids'; (b,e) presents the dry matter production in 'Regina de Verão'; and (c,f) presents the dry matter production in 'Delícia'. *, ** and ns means significance at $1 \%, 5 \%$ probability and not significant by $\mathrm{F}$ test, respectively.

'Grand Rapids' had the best growth in response to $\mathrm{Zn}$ application in soils, yielding 16.0 and $9.0 \mathrm{~g}$ SDM per plant in RYL and dRL, respectively, with Zn doses of up to $15.6 \mathrm{mg} \mathrm{kg}^{-1}$ (Figure 1a). The 'Regina de Verão' and 'Delicia' genotypes had different responses to the tested soils. When both were grown in RYL, growth was constantly reduced by increasing Zn applications, achieving about 91\% ('Regina de Verão') and 42\% ('Delicia') lower yields of SDM at the maximum dose compared to the control. By contrast, 'Regina de Verão' and 'Delícia' yielded maximum values of 2.7 and $6.7 \mathrm{~g}$ SDM per plant, at the estimated Zn doses of 15.2 and $16.0 \mathrm{mg} \mathrm{kg}^{-1}$ in the dRL (Figure 1b,c).

Root system growth was affected by treatments in all three lettuce genotypes. The 'Grand Rapids' lettuce reached $2.7 \mathrm{~g}$ of RDM per plant in RYL with Zn doses of $15.2 \mathrm{mg} \mathrm{kg}^{-1}$. On the other hand, the RDM yield in dRL remained stable (2.0 g per plant) at up to $10 \mathrm{mg} \mathrm{kg}^{-1}$ of $\mathrm{Zn}$ and thereafter decreased (Figure 1d). 'Regina de Verão' genotypes showed maximum RDM ( $3.7 \mathrm{~g}$ per plant) in dRL at $14.2 \mathrm{mg} \mathrm{kg}^{-1}$ of $\mathrm{Zn}$, which is equivalent to a $48 \%$ increase over not applying $\mathrm{Zn}$ to the soil (Figure 1e). This lettuce genotype ('Regina de Verão') had a similar response to $\mathrm{Zn}$ fertilization when grown in RYL 
as that observed for 'Grand Rapids' grown in dRL, whose RDM yield remained around 1.8 g per plant up to a dose of $10 \mathrm{mg} \mathrm{kg}^{-1}$, decreasing thereafter up to the $\mathrm{Zn}$ dose of $30 \mathrm{mg} \mathrm{kg}^{-1}$ (Figure 1e).

The 'Delícia' lettuce root growth decreased with the $\mathrm{Zn}$ application when grown in RYL, reaching the lowest RDM yield ( $0.8 \mathrm{~g}$ per plant) at a $\mathrm{Zn}$ dose of $20 \mathrm{mg} \mathrm{kg}^{-1}$. This is a $65 \%$ lower RDM than in plants grown without $\mathrm{Zn}$ fertilization (Figure 1f). However, the 'Delicia' genotype had increased growth in dRL up to the $\mathrm{Zn}$ dose of $16.7 \mathrm{mg} \mathrm{kg}^{-1}$ but with maximum yields lower than those reached for the other genotypes.

\subsection{Leaf Zn Concentration and Accumulation-Biofortification}

The $\mathrm{Zn}$ concentration and accumulation in lettuce genotypes were affected by both soil and micronutrient doses. The highest $\mathrm{Zn}$ concentration and accumulation in the leaves of 'Grand Rapids', 'Regina de Verão', and 'Delícia' were found in the RYL (Figure 2).
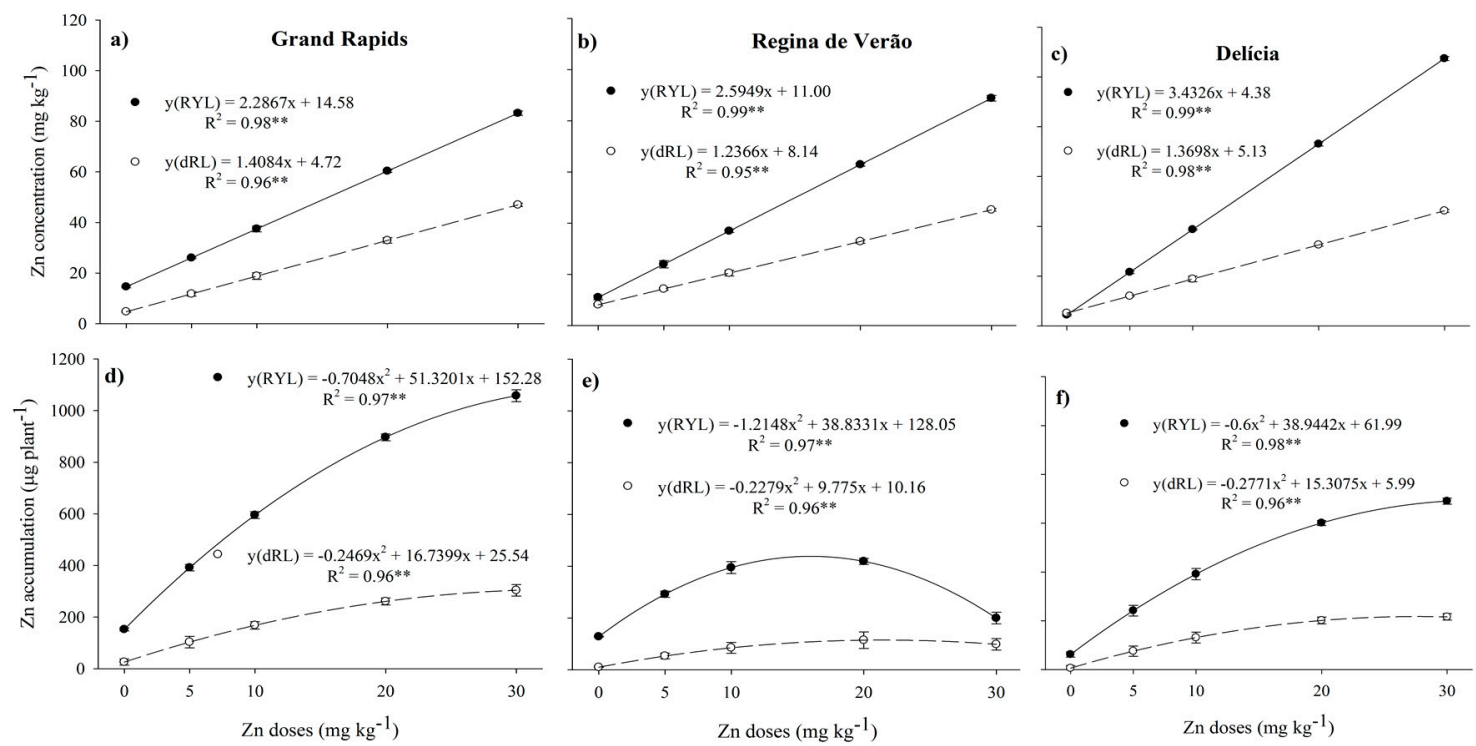

Figure 2. Zn concentration and accumulation in the shoot dry matter of three lettuce genotypes grown in Red-Yellow Latosol (RYL) and Dystroferric Red Latosol (dRL) with different Zn doses. (a,d) presents the values in 'Grand Rapids'; (b,e) presents the values in 'Regina de Verão'; and (c,f) presents the values in 'Delícia'. * ** and ns means ignificance at $1 \%, 5 \%$ probability and not significant by $\mathrm{F}$ test, respectively.

Regardless of the soil, $\mathrm{Zn}$ concentrations in the three genotypes increased linearly in response to increased $\mathrm{Zn}$ supply (Figure 2a-c). All genotypes had the same leaf concentrations when not fertilized with $\mathrm{Zn}$ in dRL. By contrast, the $\mathrm{Zn}$ concentration in leaves of the 'Grand Rapids' $\left(14.6 \mathrm{mg} \mathrm{kg}^{-1}\right)$ and 'Delícia' (4.4 mg kg-1) genotypes were different when grown in RYL. Regarding the response amplitude to the Zn supply in RYL, the 'Delícia' genotype showed a 23-fold-increase compared to that observed in unfertilized plants while 'Grand Rapids' and 'Regina de Verão' had 5- and 6-fold increases compared to the control plants, respectively.

Among the lettuce genotypes, the 'Grand Rapids' grown in RYL had the highest Zn accumulation $(1058.0 \mu \mathrm{g})$ in shoots (Figure $2 \mathrm{~d}-\mathrm{f}$ ) after the highest $\mathrm{Zn}$ dose application. This is equivalent to a $246 \%$ increase in micronutrient absorption compared to the $\mathrm{Zn}$ accumulation $(306.0 \mu \mathrm{g})$ in shoots fertilized with $30 \mathrm{mg} \mathrm{kg}^{-1}$ in dRL (Figure 2d). The 'Delícia' lettuce accumulated $690.3 \mu \mathrm{g}$ of $\mathrm{Zn}$ in shoots at a dose of $30 \mathrm{mg} \mathrm{kg}^{-1}$, i.e., a 3.2-fold greater accumulation when grown in the dRL using the same $\mathrm{Zn}$ treatment (Figure 2f).

The 'Regina de Verão' genotype had their highest $\mathrm{Zn}$ accumulation $(439.6 \mu \mathrm{g})$ with the application of an estimated dose of $16.0 \mathrm{mg} \mathrm{kg}^{-1}$ in the RYL, which was 3.8-fold higher than the maximum accumulation obtained with the $\mathrm{Zn}$ dose of $21.4 \mathrm{mg} \mathrm{kg}^{-1}$ in the dRL (Figure 2e). 
According to the correlation tests on the leaf Zn concentration and yield of SDM and RDM, lettuce genotypes responded differently to $\mathrm{Zn}$ fertilization in the two soils (Figure 3). A negative correlation was observed $(p<0.001)$ between RDM and Zn concentrations in 'Grand Rapids' $(r=-0.75)$ grown in dRL. By contrast, the 'Regina de Verão' and 'Delícia' genotypes had negative correlations between leaf $\mathrm{Zn}$ concentration and RDM ( $r=-0.78 ; r=-0.93$, respectively), and between leaf $\mathrm{Zn}$ concentration and $\operatorname{SDM}(r=-0.94 ; r=-096$, respectively) only when grown in the RYL.

\section{Grand Rapids}
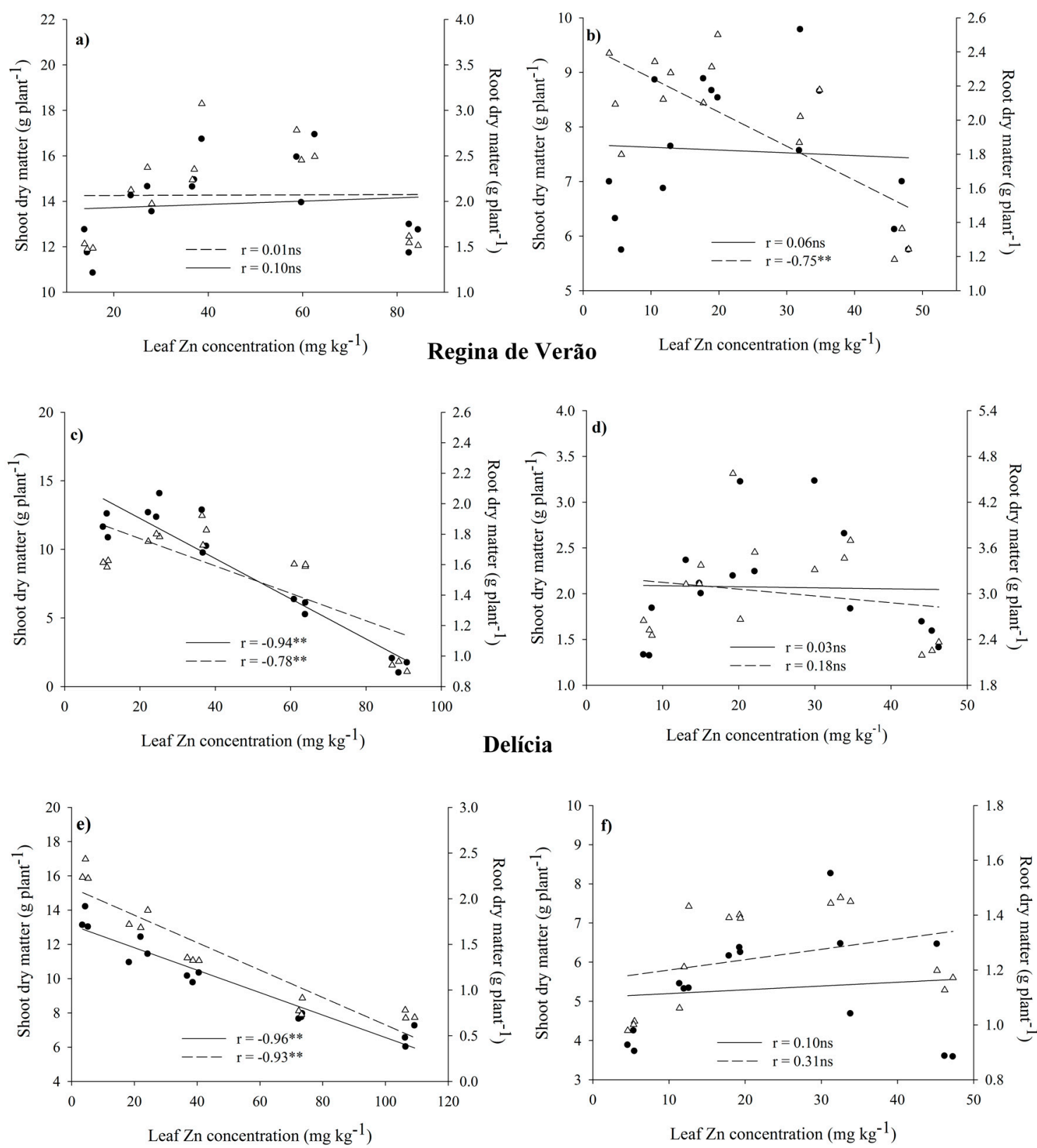

Figure 3. Correlation of leaf $\mathrm{Zn}$ concentration with shoot dry matter $(\bullet)$ and root dry matter $(\Delta)$ in three lettuce genotypes grown in Red-Yellow Latosol and Dystroferric Red Latosol with the application of different $\mathrm{Zn}$ doses. (a,c,e) presents the correlations obtained in the Red-Yellow Latosol; and $(\mathbf{b}, \mathbf{d}, \mathbf{f})$ presents the correlations obtained in the Dystroferric Red Latosol. ${ }^{*},{ }^{* *}$ and ns means significance at $1 \%, 5 \%$ probability and not significant by $\mathrm{F}$ test, respectively. 


\section{Discussion}

According to the results, all three genotypes of lettuce studied have a different ability to be biofortified in the same soil. By applying the dose for highest SDM yield, the 'Grand Rapids' (15.6 mg kg$\left.{ }^{-1}\right)$, 'Regina de Verão' $\left(4.4 \mathrm{mg} \mathrm{kg}^{-1}\right)$, and 'Delícia' $\left(0 \mathrm{mg} \mathrm{kg}^{-1}\right)$ genotypes accumulated $781.3,265.4$, and $61.9 \mu \mathrm{g}$ of $\mathrm{Zn}$ in the shoots of plants grown in RYL, respectively. Therefore, the 'Grand Rapids' genotype was enriched more with Zn without a loss of yield and presented a greater capacity for $\mathrm{Zn}$ biofortification. Micronutrient fertilization has been more successful in increasing the $\mathrm{Zn}$ concentration in the edible portion of leafy vegetables $[13,16,23]$ than plants whose edible parts are reserve organs [17].

A similar linear increase of the leaf $\mathrm{Zn}$ concentration as in the three lettuce genotypes in both soils (Figure 2) was also found by White et al. [16] on genotypes of cabbage and broccoli grown in substrate. This is because the plants are natural extractors of minerals from the soil, without the distinction of how much is absorbed. This leads to phytotoxicity and consequently low crop yields, as found in our results (Figure 1). The increased availability of this micronutrient in soil coupled with its predominantly xylem transport causes a greater concentration in the organs (leaves) with s higher transpiratory rate [24]. However, the SDM yield was significantly reduced in all three genotypes at the dose of $30 \mathrm{mg} \mathrm{kg}^{-1}$, because, although lettuce leaves were strongly $\mathrm{Zn}$ enriched, their biofortification capacity was limited by phytotoxicity.

Moreover, the Zn availability from fertilizer depends on the soil conditions or types. The soils used in our study (Table 1) differed regarding their ability to make $\mathrm{Zn}$ available to plants and consequently biofortify lettuce genotypes. The clay-textured dRL has a lower concentration of $\mathrm{P}$ and and $\mathrm{Mn}^{2+}$, higher buffer capacity, higher $\mathrm{Fe}$ and $\mathrm{Al}$ oxide contents, and higher organic matter and gibbsite $(35.9 \%)$ than RYL. These features increase Zn adsorption and decrease its availability to plants [23,25]. In addition, increasing $\mathrm{pH}$ by liming in both soils may also reduce the availability of this micronutrient, especially in dRL [26]. Pongrac et al. [23] found that soil types affected red cabbage growth more than phosphorus and $\mathrm{Zn}$ treatments. Therefore, these authors concluded that more studies in different types of soils are necessary to investigate their impact on the biofortification of the edible parts of crops. This suggests that the increases in the concentrations of essential mineral elements in the edible portions of crops are subject to the plant absorption capacity and to the restrictions imposed by the environment [16].

The biofortification methods should be used considering the genotype $\times$ soil interaction, since genotypes distinctly respond to different soils [10]. 'Regina de Verão' and 'Delicia' grown in RYL had the lowest tolerance to an increase in micronutrient concentrations, as demonstrated by the negative correlation found in these genotypes between biomass production and leaf $\mathrm{Zn}$ concentration (Figure 3c,e). Thus, we recommend biofortification with 7.8 and $3.7 \mathrm{mg} \mathrm{kg}^{-1}$ of $\mathrm{Zn}$ to the RYL and $\mathrm{dRL}$, respectively, since higher doses resulted in a 10\% loss of SDM yield of these genotypes. At these doses, we reached 31.2 and $17.1 \mathrm{mg} \mathrm{kg}^{-1}$ of $\mathrm{Zn}$ in the SDM of the 'Regina de Verão' and 'Delicia' genotypes, respectively. By contrast, the Zn dose of $15.6 \mathrm{mg} \mathrm{kg}^{-1}$ in the RYL maximized the SDM yield of 'Grand Rapids' and increased the leaf Zn concentration up to $50.3 \mathrm{mg} \mathrm{kg}^{-1}$, almost a $250 \%$ higher micronutrient concentration than in plants not fertilized with $\mathrm{Zn}$. If we consider the possibility of a $10 \%$ yield loss in SDM as in the other genotypes, 'Grand Rapids' would have its biofortification increased to $83.2 \mathrm{mg} \mathrm{kg}^{-1} \mathrm{Zn}$. On the other hand, 'Delícia' was the genotype with the highest $\mathrm{Zn}$ concentration (27.1 mg kg-1) in SDM, followed by 'Grand Rapids' with $25.7 \mathrm{mg} \mathrm{kg}^{-1}$, both grown in dRL soil.

The average concentration of $\mathrm{Zn}\left(43.8 \mathrm{mg} \mathrm{kg}^{-1}\right)$ from the highest leaf $\mathrm{Zn}$ concentrations were found for 'Regina de Verão' (31.2 $\left.\mathrm{mg} \mathrm{kg}^{-1}\right)$, 'Delicia' (17.1 $\left.\mathrm{mg} \mathrm{kg}^{-1}\right)$, and 'Grand Rapids' (83.2 $\mathrm{mg} \mathrm{kg}^{-1}$ ) without a loss of SDM yield. Therefore, if we assume that a daily serving size of the $\mathrm{Zn}$-enriched lettuce is approximately $30 \mathrm{~g}$ fresh weight (or $3 \mathrm{~g}$ dry weight due to its $90 \%$ water content), consumption of the average $\mathrm{Zn}$-containing lettuce $\left(43.8 \mathrm{mg} \mathrm{kg}^{-1}\right)$ would result in the ingestion of $0.13 \mathrm{mg} \mathrm{Zn}$, equivalent to $1.2 \%$ of the recommended dietary allowance for $\mathrm{Zn}\left(\mathrm{RDA} ; 11 \mathrm{mg} \mathrm{day}^{-1} \mathrm{Zn}\right.$ ). Although these increments 
pose a small contribution to people's daily $\mathrm{Zn}$ intake, due to being the most widely produced and consumed leafy vegetable in the world, its biofortification will contribute to $\mathrm{Zn}$ intake.

Our results confirm the hypothesis of interaction between lettuce genotypes and soil conditions on the efficiency of agronomic biofortification supported by other studies $[8,23]$. Therefore, genetic and agronomic biofortification programs should be improved together, as their success depends on each other. Regardless of whether a new cultivar developed can absorb Zn, its success will depend on the availability of the $\mathrm{Zn}$ pool in the soil. In addition, plant breeding seems to be the most viable and economical way to reach rural populations with limited access to agronomically biofortified crops [14].

\section{Conclusions}

Lettuce genotypes responded differently to $\mathrm{Zn}$ application depending on the type of soil where they were grown.

Lettuce had better response to agronomic biofortification with Zn in a medium-textured Red-Yellow Latosol, with a lower buffer capacity and lower Zn adsorption than when grown in Dystroferric Red Latosol.

Author Contributions: Conceptualization, M.F.I. and A.E.F.N.; Formal analysis, M.F.I. and V.M.V.C.; Investigation, M.F.I. and H.J.d.A.; writing-original draft preparation, M.F.I. and H.J.d.A.; writing-review and editing, H.J.d.A., V.M.V.C., M.M. and A.B.C.F.; supervision, A.E.F.N.; project administration, M.F.I. and A.E.F.N.; funding acquisition, M.F.I. and H.J.d.A. All authors have read and agreed to the published version of the manuscript.

Funding: This research received no external funding.

Acknowledgments: To CNPq for granting the scholarship to the first and third authors, and to UFLA's Department of Soil Science for providing all the necessary conditions for the experiment.

Conflicts of Interest: The authors declare no conflict of interest.

\section{References}

1. Worldmeters. Available online: http://www.worldometers.info/world-population/\#growthrate (accessed on 27 September 2019).

2. United Nations. The Impact of Population Momentum on Future Population Growth; United Nations: New York, NY, USA, 2017.

3. Sustainable Development Solutions Network. Solutions for Sustainable Agriculture and Food Systems: Technical Report for the Post-2015 Development Agenda; Sustainable Development Solutions Network: New York, NY, USA, 2015.

4. Godfray, H.C.J.; Beddington, J.R.; Crute, I.R.; Haddad, L.; Lawrence, D.; Muir, J.F.; Pretty, J.; Robinson, S.; Thomas, S.M.; Toulmin, C. Food Security: The challenge of feeding 9 billion people. Science 2010, 327, 812-818. [CrossRef] [PubMed]

5. FAO; WFP; IFAD. Economic growth is necessary but not sufficient to accelerate reduction of hunger and malnutrition. In The State of Food Insecurity in the World 2012; FAO: Rome, Italy, 2012.

6. Beal, T.; Massiot, E.; Joanne, E.; Arsenault, J.E.; Matthew, R.; Smith, M.R.; Hijmans, R.J. Global trends in dietary micronutrient supplies and estimated prevalence of inadequate intakes. PLoS ONE 2017, 12, e0175554. [CrossRef] [PubMed]

7. Wessells, K.R.; Brown, K.H. Estimating the global prevalence of zinc deficiency: Results based on zinc availability in national food supplies and the prevalence of stunting. PLoS ONE 2012, 7, e50568. [CrossRef] [PubMed]

8. Hefferon, K. Biotechnological approaches for generating zinc-enriched crops to combat malnutrition. Nutrients 2019, 11, 253. [CrossRef] [PubMed]

9. Lopes, A.S.; Guilherme, L.R.G. A career perspective on soil management in the Cerrado region of Brazil. Adv. Agron. 2016, 137, 1-72.

10. Corguinha, A.P.B.; Carvalho, C.A.; de Souza, G.A.; de Carvalho, T.S.; Vieira, E.A.; Fialho, J.F.; Guilherme, L.R.G. Potential of cassava clones enriched with $\beta$-carotene and lycopene for zinc biofortification under different soil Zn conditions. J. Sci. Food Agric. 2019, 99, 666-674. [CrossRef] [PubMed] 
11. Tittonell, P.; Giller, K.E. When yield gaps are poverty traps: The paradigm of ecological intensification in african smallholder agriculture. Field Crop. Res. 2013, 143, 76-90. [CrossRef]

12. Manzeke, M.G.; Mtambanengwe, F.; Nezomba, H.; Watts, M.J.; Broadley, M.R.; Mapfumo, P. Zinc fertilization increases productivity and grain nutritional quality of cowpea (Vigna unguiculata [L.] Walp.) under integrated soil fertility management. Field Crop. Res. 2017, 213, 231-244. [CrossRef]

13. Barrameda-Medina, Y.; Blasco, B.; Lentini, M.; Esposito, S.; Baenas, N.; Moreno, D.A.; Ruiz, J.M. Zinc biofortification improves phytochemicals and amino-acidic profile in Brassica oleracea cv. Bronco. Plant Sci. 2017, 258, 45-51. [CrossRef] [PubMed]

14. Bouis, H.E.; Saltzman, A. Improving nutrition through biofortification: A review of evidence from HarvestPlus, 2003 through 2016. Glob. Food Secur. 2017, 12, 49-58. [CrossRef] [PubMed]

15. Poblaciones, M.J.; Rengel, Z. Soil and foliar zinc biofortification in field pea (Pisum sativum L.): Grain accumulation and bioavailability in raw and cooked grains. Food Chem. 2016, 212, 427-433. [CrossRef] [PubMed]

16. White, P.J.; Pongrac, P.; Sneddon, C.C.; Thompson, J.A.; Wright, G. Limits to the biofortification of leafy brassicas with zinc. Agriculture 2018, 8, 32. [CrossRef]

17. White, P.J.; Broadley, M.R. Physiological limits to zinc biofortification of edible crops. Front. Plant Sci. 2011, 2, 1-11. [CrossRef] [PubMed]

18. Maynard, D.N.; Hochmuth, G.J. Knott's Handbook for Vegetable Growers, 5th ed.; John Wiley \& Sons, Inc.: Hoboken, NJ, USA, 2007; pp. 179-181.

19. Padash, A.; Shahabivand, S.; Behtash, F.; Aghaee, A. A practicable method for zinc enrichment in lettuce leaves by the endophyte fungus Piriformospora indica under increasing zinc supply. Sci. Hortic. 2016, 213, 367-372. [CrossRef]

20. Faostat. Available online: http://www.fao.org/faostat/es/\#data/QC (accessed on 29 December 2019).

21. Souza, R.F.; Faquin, V.; Fernandes, L.A.; Avila, F.W. Nutrição fosfatada e rendimento do feijoeiro sob influência da calagem e adubação orgânica. Ciênc. Agrotec. 2006, 30, 656-664. [CrossRef]

22. Barbosa, J.C.; Maldonado Júnior, W. Experimentação Agronômica e Agroestat-Sistema Para Análises Estatísticas de Ensaios Agronômicos, 1st ed.; Gráfica Multipress Ltda: Jaboticabal, Brazil, 2015.

23. Pongrac, P.; McNicol, J.W.; Lilly, A.; Thompson, J.A.; Wright, G.; Hillier, S.; White, P.J. Mineral element composition of cabbage as affected by soil type and phosphorus and zinc fertilization. Plant Soil 2019, 434, 151-165. [CrossRef]

24. Taiz, L.; Zeiger, E.; Moller, I.M.; Murphy, A. Fisiologia e Desenvolvimento Vegetal, 6th ed.; Artmed: Porto Alegre, Brazil, 2017; pp. 119-167.

25. Rafaey, Y.; Jansen, B.; Parsons, J.R.; Voogt, P.; Bagnis, S.; Markus, A.; El-Shater, A.-H.; El-Haddad, A.-A.; Kalbitz, K. Effects of clay minerals, hydroxides, and timing of dissolved organic matter addition on the competitive sorption of copper, nickel, and zinc: A column experiment. J. Environ. Manag. 2017, 187, 273-285. [CrossRef] [PubMed]

26. Broadley, M.; Brown, P.; Cakmak, I.; Rengel, Z.; Zhao, F. Function of nutrients: Micronutrients. In Marschner's Mineral Nutrition of Higher Plants, 3rd ed.; Marschner, P., Ed.; Academic Press: London, UK, 2012; pp. 191-248. 